\title{
Committed subcutaneous preadipocytes are reduced in human obesity
}

\author{
Y. Tchoukalova • C. Koutsari • M. Jensen
}

Received: 4 August 2006 / Accepted: 7 September 2006 / Published online: 10 November 2006

(C) Springer-Verlag 2006

\begin{abstract}
Aims/hypothesis The aim of this study was to test whether the availability of committed preadipocytes in abdominal and femoral subcutaneous adipose tissue varies with obesity and body fat distribution.

Methods Body composition, fat cell size, committed preadipocytes and macrophages were measured in subcutaneous abdominal and femoral adipose depots of 17 lean, 16 upper-body-obese (UBO) and 13 lower-body-obese (LBO) women. Preadipocytes and macrophages were identified by simultaneous staining with the respective markers aP2 and CD68. In a subset of samples we measured preadipocyte proliferation, differentiation and susceptibility to apoptosis. Results Abdominal adipocytes were smaller in lean than in obese women. Committed preadipocytes represented a greater fraction of stromovascular cells in lean than in obese women but were similar between UBO and LBO women (abdomen: $\sim 30 \pm 3$ vs $\sim 17 \pm 2 \%$; thigh: $\sim 30 \pm 3$ vs $\sim 17 \pm 2 \%$ ). Preliminary data suggested that preadipocyte kinetics were similar in LBO and lean women, whereas preadipocytes of UBO women differentiated less and were more susceptible to apoptotic stimuli. The fraction of stromovascular cells that were macrophages was greater in both depots in obese women (UBO and LBO) than in normal-weight women, but the difference was not statistically significant.
\end{abstract}

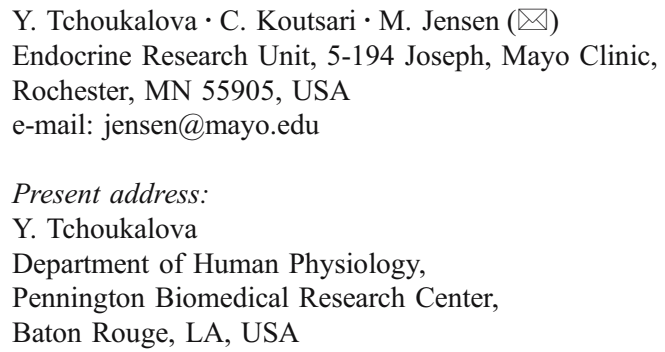

Conclusions/interpretation The proportion of subcutaneous adipose tissue stromovascular cells that are committed preadipocytes is reduced with obesity. This could be due to greater recruitment of preadipocytes to adipogenesis or greater preadipocyte apoptosis, depending upon the obesity phenotype. These data are consistent with the concept that body fat distribution may be regulated partly through differences in adipogenesis.

Keywords aP2 - Body fat distribution · CD68 - Fat cell size · Macrophages $\cdot$ Preadipocytes
Abbreviations
BrdU bromodeoxyuridine
IBMX 3-isobutyl-1-methylxanthine
LBO lower-body obese
sTSH sensitive thyroid-stimulating hormone
UBO upper-body obese

\section{Introduction}

Obesity is defined by an excess of adipose tissue, most of which $(\sim 80 \%)$ is normally found in the subcutaneous depots. The relative distribution of subcutaneous fat varies between individuals with the same BMI [1]. Some people have more uniformly distributed subcutaneous fat and others have relatively more in either the lower or the upper body. Upper-body obesity is often accompanied by visceral fat accumulation, insulin resistance and other metabolic abnormalities. Although there are some regional differences in fat cell size, adipocyte hypertrophy cannot account for the entire gain of fat in obesity or the entire variation in regional fat gain. This indicates that regional adipocyte hyperplasia probably occurs in humans. 
Adipocyte hyperplasia should be dependent upon preadipocyte availability. We developed a method to identify the proportion of stromovascular cells in adipose tissue which are committed preadipocytes by immunofluorescent staining for the intracellular adipocyte fatty acid binding protein known as aP2 [2]. This technique allows the determination of between-site and/or inter-individual differences in the number of committed preadipocytes. In this study we tested whether the preadipocyte fractions of stromovascular cells isolated from abdominal and femoral adipose depots are different among lean, upper-body-obese (UBO) and lower-bodyobese (LBO) women.

\section{Subjects and methods}

\section{Subjects}

The experimental protocols were approved by Mayo Foundation Institutional Review Board. Premenopausal women between the ages of 18 and 49 years were included in the study. The lean control subjects $(n=17)$ had a BMI $<25 \mathrm{~kg} / \mathrm{m}^{2}$. Obese women had a BMI in the range of $28-36 \mathrm{~kg} / \mathrm{m}^{2}$; those with a WHR of $<0.76$ were defined as LBO $(n=13)$ and those with WHR $>0.85$ were defined as UBO $(n=16)$. Women taking corticosteroids were not eligible. Women taking thyroid hormone replacement were eligible if their sensitive thyroidstimulating hormone (sTSH) was within the normal range.

\section{Study design}

We obtained written informed consent from the volunteers. They arrived at the Mayo General Clinical Research Center in the morning after an overnight fast. Blood was obtained for pregnancy testing and measurement of fasting plasma glucose, insulin and lipids (total cholesterol and HDL-cholesterol, triacylglycerol). Waist and hip circumferences were measured as described previously [3]. Total body fat and the amounts of lowerbody and upper-body subcutaneous adipose tissue and visceral adipose tissue were measured or estimated using dual-energy X-ray absorptiometry and single-slice computed tomography of the abdomen [4]. Approximately $150 \mathrm{mg}$ to $2 \mathrm{~g}$ of adipose tissue was obtained by needle biopsy from the lateral periumbilical region of the subcutaneous abdominal and lateral thigh areas. We extracted the lipids from $\sim 100 \mathrm{mg}$ of adipose tissue [5]. The remaining adipose tissue in the biopsy sample was digested enzymatically to isolate the adipocytes and stromovascular cells.
Fat cell size and number per gram of tissue

Digital photomicrographs of at least 300 cells were taken at $100 \times$ and sized using an in-house automated software program that had been validated against direct microscopy of isolated adipocytes [6]. Lipid content per gram of tissue was determined from the extracted lipid. Fat cell number was calculated by dividing the lipid amount per gram of tissue by the mean fat cell size.

\section{Immunofluorescence}

The stromovascular cells were cytospun, dried for $24 \mathrm{~h}$ and then stained using a rabbit anti-aP2 antibody (a gift from D. A. Bernlohr, University of Minnesota), diluted $100 \times$ in a ready-to-use mouse anti-human CD68 antibody (KP1; Dako Cytomation, Carpinteria, CA, USA) supplemented with saponin to a final concentration of $0.1 \%$. The primary antibodies were detected with fluorescently labelled secondary antibodies as described previously [2]. Control stromovascular cells were stained in parallel using combined ready-to-use universal anti-mouse and anti-rabbit antibodies (Dako Cytomation) and used to set the threshold for specificity each time images were taken with a LSM510 confocal microscope. We counted at least 1,000 nuclei (blue) with KS-400 image analysis software (Carl Zeiss, Oberkochen, Germany), after which the numbers of singlestained cells $\left[\mathrm{aP}^{+} \mathrm{CD}^{-} 8^{-}\right.$(green) and $\mathrm{aP}^{-} \mathrm{CD} 68^{+}$(red)] and dual-stained cells $\left(\mathrm{aP} 2^{+} \mathrm{CD} 68^{+}\right.$, green and red) were counted manually. Thus, the percentages of preadipocytes $\left(\mathrm{aP} 2^{+} \mathrm{CD} 68^{-}\right.$cells) and macrophages $\left(\mathrm{aP}^{-} \mathrm{CD} 68^{+}\right.$plus $\mathrm{aP} 2^{+} \mathrm{CD} 68^{+}$cells) among the stromovascular cells were calculated.

Preadipocyte dynamics

Stromovascular cells from abdominal and femoral subcutaneous adipose tissue of three LBO, three UBO and five lean women were seeded in DMEM-Ham's F-12 (1:1) medium enriched with $10 \%$ fetal bovine serum (FBS) as described previously [7]. After reaching $\sim 80 \%$ confluence, cells were detached using $0.25 \%$ trypsin and passaged twice. Cells were then frozen in DMEM-Ham's F-12 (1:1) medium containing 50\% FBS and 5\% DMSO until all samples had been collected. On the day of assessment of preadipocyte kinetics, the frozen stromovascular cells from the third subculture were thawed and plated in duplicate onto circular coverglasses inserted in 24-well plates in DMEMHam's F-12 (1:1) containing 10\% FBS at a density of $1 \times$ 104 cells $/ \mathrm{cm}^{2}$ for each of the following assays.

Differentiation assay: oil red $O$ staining After reaching $\sim 80 \%$ confluence, medium was switched to inducing 
differentiation medium: DMEM-Ham's F-12 (1:1) plus $10 \mathrm{mg} / \mathrm{ml}$ transferrin, $33 \mu \mathrm{mol} / 1$ biotin, $17 \mu \mathrm{mol} / 1$ calcium pantothenate, $0.5 \mu \mathrm{mol} / 1$ insulin, $0.1 \mu \mathrm{mol} / 1$ dexamethasone, $2 \mathrm{nmol} / \mathrm{l}$ triiodothyronine, $0.5 \mu \mathrm{mol} / 1$ roziglitazone and $540 \mu \mathrm{mol} / 1 \mathrm{IBMX}$. The IBMX was used for the first 2 days only. After 11-13 days, adipocytes were stained for lipids with Oil Red $\mathrm{O}$ and nuclei were counterstained with Harris haematoxylin as described previously [8]. Images were taken using a Nikon Coolpix 990 digital camera attached to a Nikon Labophot 2/2A microscope (Fig. 1a). The total numbers of nuclei (blue) and adipocytes (red) were counted manually and the percentage of fat cells was calculated by a technician blind to the subject groups.

Proliferation assay: bromodeoxyuridine staining After $24 \mathrm{~h}$ of plating, cells were labelled using bromodeoxyuridine (BrdU) labelling reagent (Zymed Laboratories, Invitrogen Corporation, Carlsbad, CA, USA; diluted 100×) for $12 \mathrm{~h}$. Negative controls were not labelled with BrdU. Cells were fixed in ice-cold methanol-glacial acetic acid (1:1) for $15 \mathrm{~min}$. DNA was denatured with $2 \mathrm{~N} \mathrm{HCl}$ for $30 \mathrm{~min}$ followed by incubation in $0.1 \mathrm{~mol} / \mathrm{l}$ sodium borate buffer ( $\mathrm{pH} 8.5$ ), twice for $10 \mathrm{~min}$ each time, to neutralise the $\mathrm{pH}$. Non-specific binding was blocked with Dako protein blocking buffer for $20 \mathrm{~min}$. Cells were incubated in antiBrdU (Ab-3) mouse monoclonal antibody NA61 $(1 \mu \mathrm{g} / \mathrm{ml}$; Calbiochem, San Diego, CA, USA) for $1 \mathrm{~h}$ at room temperature and then in goat anti-mouse $\operatorname{IgG}$ conjugated with Alexa 488 fluorochrome $(10 \mu \mathrm{g} / \mathrm{ml}$; Invitrogen Molecular Probes, Carlsbad, CA, USA) for $30 \mathrm{~min}$ at room temperature. Nuclei were stained with $20 \mu \mathrm{g} / \mathrm{ml}$ of 7 amino-actinomycin D (7-AAD). Cover glasses were taken out, inverted and mounted onto glass slides using ProLong Antifade kit (Molecular Probes, Eugene, OR, USA). Images were taken with a confocal microscope (Fig. 1b). Red fluorescence from 7-AAD was excited with a $543 \mathrm{~nm}$ helium-neon laser. Emission was collected through a 560$\mathrm{nm}$ long-pass filter. The total number of nuclei (red, at least 500) and the number of nuclei with DNA that had

Fig. 1 Representative images from simultaneous assessment of preadipocyte dynamics in stromovascular third subculture. a Differentiation. Oil Red O staining of lipid containing in vitro-differentiated adipocytes (red) after 11-13 days of treatment of confluent cultures with serum-free differentiation medium. Nuclei were counterstained with haematoxylin (blue). b Proliferation. Preconfluent cells were labelled with BrdU for $12 \mathrm{~h}$. Dividing cells that had incorporated BrdU in their newly synthesised DNA (BrdU ${ }^{+}$cells) were visualised by immunofluorescence using an anti-BrdU antibody. Nuclei were counterstained with 7-AAD (red), and $\mathrm{BrdU}^{+}$nuclei (green plus red) appear yellow. c Apoptosis. Confluent cultures were induced to undergo apoptosis with $10 \mathrm{nmol} / 1 \mathrm{TNF}-\alpha$ and $10 \mu \mathrm{g} / \mathrm{ml}$ cycloheximide for $6 \mathrm{~h}$. Nuclei were stained with Hoechst 33258 and analysed for morphological features of apoptosis (fragmentation [arrow] and condensation [arrowhead $]$ )
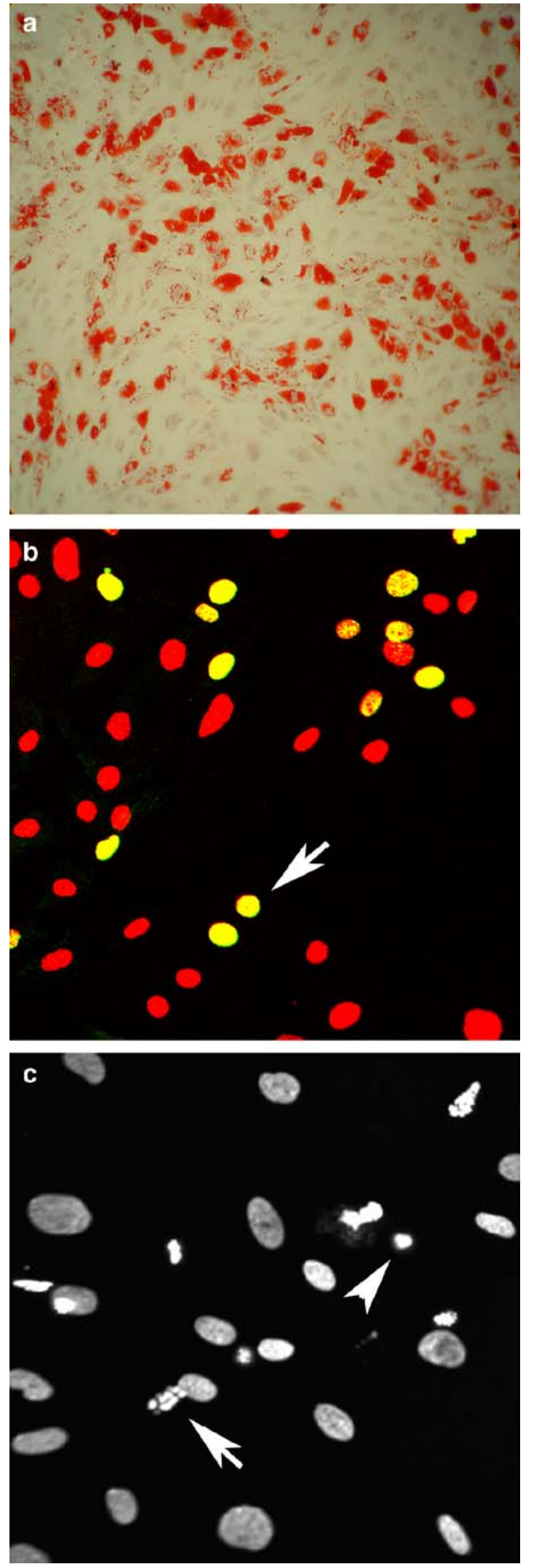
incorporated BrdU (green) were counted automatically using KS-400 image analysis software (Carl Zeiss) and the percentage of $\mathrm{BrdU}^{+}$cells was calculated.

Apoptosis assay: nuclear morphology After confluence had been reached, apoptosis was induced in a separate set of plates by switching to serum-free DMEM-Ham's F-12 (1:1) medium enriched with $10 \mathrm{nmol} / 1 \mathrm{TNF}-\alpha$ and $10 \mu \mathrm{g} / \mathrm{ml}$ cycloheximide (an inhibitor of protein synthesis) as described previously [9]. After $6 \mathrm{~h}$ the cells were fixed in ice-cold methanol-glacial acetic acid (1:1) for $15 \mathrm{~min}$, nuclei were stained with Hoechst 33258 and images were collected with a confocal microscope. A technician blinded to the subject groups determined the proportion of cells with morphological features of apoptosis (i.e. fragmented and/or condensed nuclei) (Fig. 1c).

\section{Statistical analysis}

The effects of obesity, obesity phenotype and adipose depot on adipose cellular parameters were tested by ANOVA with age as covariate. Differences in anthropometric and metabolic characteristics among groups were tested by ANOVA. We performed additional pairwise comparisons using Tukey adjustment when a significant effect was found with ANOVA. A $p$ value less than 0.05 was considered to indicate statistical significance.

\section{Results}

Metabolic characteristics and body composition

Subject characteristics are provided in Table 1. Although all women were premenopausal, the average age of the UBO women participating was somewhat greater than those of the LBO and non-obese women. Fasting plasma glucose, insulin and triacylglycerol concentrations were highest in UBO women, intermediate in LBO women and lowest in lean women. Obese women had a lower HDL-cholesterol concentration than lean women. Serum total cholesterol concentrations were similar among groups. The differences among groups in body fat mass and distribution were as expected, given our selection criteria. Visceral fat mass constituted higher proportions of total fat mass in UBO than in LBO and lean women but upper-body subcutaneous fat (relative to the total amount of body fat) was lower in LBO women than in UBO and lean women. The relative contribution of lower-body fat to total fat mass was in the order $\mathrm{LBO}>$ lean $>$ UBO.

Table 1 Characteristics of the study groups

\begin{tabular}{|c|c|c|c|}
\hline \multirow[t]{2}{*}{ Variable } & \multirow{2}{*}{$\begin{array}{l}\text { Lean } \\
(n=17)\end{array}$} & \multicolumn{2}{|l|}{ Obese } \\
\hline & & $\begin{array}{l}\text { Upper body } \\
(n=16)\end{array}$ & $\begin{array}{l}\text { Lower body } \\
(n=13)\end{array}$ \\
\hline Age (years) & $29.2 \pm 1.8^{\mathrm{a}}$ & $41.6 \pm 1.4^{\mathrm{b}}$ & $34.6 \pm 2.6^{\mathrm{a}}$ \\
\hline Body weight (kg) & $58.3 \pm 1.7^{\mathrm{a}}$ & $87.7 \pm 1.8^{\mathrm{b}}$ & $88.7 \pm 2.4^{\mathrm{b}}$ \\
\hline BMI $\left(\mathrm{kg} / \mathrm{m}^{2}\right)$ & $22.1 \pm 0.6^{\mathrm{a}}$ & $32.9 \pm 0.6^{\mathrm{b}}$ & $32.2 \pm 0.8^{\mathrm{b}}$ \\
\hline Waist circumference $(\mathrm{cm})$ & $74.1 \pm 1.2^{\mathrm{a}, \mathrm{d}}$ & $101.1 \pm 1.3^{\mathrm{a}}$ & $90.8 \pm 1.4^{\mathrm{b}}$ \\
\hline Hip circumference $(\mathrm{cm})$ & $94.9 \pm 1.8^{\mathrm{a}, \mathrm{d}}$ & $114.1 \pm 1.3^{\mathrm{a}}$ & $122.0 \pm 1.8^{\mathrm{b}}$ \\
\hline WHR & $0.78 \pm 0.02^{\mathrm{d}}$ & $0.89 \pm 0.01$ & $0.74 \pm 0.005$ \\
\hline Total cholesterol (mmol/l) & $4.2 \pm 0.1$ & $4.7 \pm 0.2$ & $4.4 \pm 0.3$ \\
\hline HDL-cholesterol (mmol/l) & $1.6 \pm 0.1^{\mathrm{a}}$ & $1.1 \pm 0.1^{\mathrm{b}}$ & $1.3 \pm 0.1^{\mathrm{b}}$ \\
\hline Serum triacylglycerol $(\mathrm{mmol} / \mathrm{l})$ & $0.8 \pm 0.1^{\mathrm{a}}$ & $1.6 \pm 0.1^{\mathrm{b}}$ & $0.9 \pm 0.1^{\mathrm{a}}$ \\
\hline Fasting glucose $(\mathrm{mmol} / \mathrm{l})$ & $4.8 \pm 0.1^{\mathrm{a}}$ & $5.2 \pm 0.1^{\mathrm{b}}$ & $5.1 \pm 0.1^{\mathrm{ab}}$ \\
\hline Fasting insulin $(\mathrm{pmol} / \mathrm{l})$ & $27.8 \pm 2.1^{\mathrm{a}}$ & $69.5 \pm 13.9^{\mathrm{b}}$ & $41.7 \pm 6.9^{\mathrm{a}, \mathrm{b}}$ \\
\hline Total fat mass $(\mathrm{kg})$ & $17.4 \pm 0.8^{\mathrm{a}}$ & $38.2 \pm 1.2^{\mathrm{b}}$ & $44.6 \pm 4.7^{\mathrm{b}}$ \\
\hline UB subcutaneous fat mass $(\mathrm{kg})$ & $9.4 \pm 0.4^{\mathrm{a}}$ & $20.3 \pm 0.8^{\mathrm{b}}$ & $19.8 \pm 0.7^{\mathrm{b}}$ \\
\hline LB subcutaneous fat mass $(\mathrm{kg})$ & $7.0 \pm 0.3^{\mathrm{a}}$ & $13.1 \pm 0.4^{\mathrm{b}}$ & $18.8 \pm 1.0^{\mathrm{c}}$ \\
\hline Visceral fat mass (kg) & $1.0 \pm 0.2^{\mathrm{a}}$ & $4.0 \pm 0.5^{\mathrm{b}}$ & $2.7 \pm 0.4 \mathrm{c}$ \\
\hline Total fat ( $\%$ of body weight) & $30.8 \pm 1.3^{\mathrm{a}}$ & $45.2 \pm 0.7^{\mathrm{b}}$ & $48.9 \pm 1.3^{\mathrm{b}}$ \\
\hline UB subcutaneous fat ( $\%$ of total fat mass) & $54.2 \pm 0.9^{\mathrm{a}}$ & $54.3 \pm 1.1^{\mathrm{a}}$ & $48.3 \pm 0.9^{b}$ \\
\hline LB subcutaneous fat ( $\%$ of total fat mass) & $40.3 \pm 0.9^{\mathrm{a}}$ & $35.2 \pm 1.0^{\mathrm{b}}$ & $45.3 \pm 1.6^{\mathrm{c}}$ \\
\hline Visceral fat ( $\%$ of total fat mass) & $5.5 \pm 0.8^{\mathrm{a}}$ & $10.5 \pm 1.0^{\mathrm{b}}$ & $6.4 \pm 0.6^{\mathrm{a}}$ \\
\hline
\end{tabular}

Values are means \pm SEM.

$L B$ lower body, $U B$ upper body

${ }^{\mathrm{a}-\mathrm{c}}$ Different superscripts within a row indicate $p<0.05$.

${ }^{\mathrm{d}}$ Data from nine (out of 17) lean women 
Adipocytes

Adipocytes from both subcutaneous depots of lean women were smaller than those from the corresponding depots of obese women of either phenotype (Table 2). We found no difference in abdominal adipocyte size between UBO and LBO women. Thigh adipocytes were larger than abdominal adipocytes in lean women $(p=0.0006)$, but there was no significant difference in adipocyte size between the two depots in either the UBO or the LBO women. Fat cell number was similar in all groups and depots except in the abdominal depot in lean women, where there were more cells per gram of tissue.

\section{Preadipocytes}

In lean women, approximately $30 \%$ of stromovascular cells were found to be committed preadipocytes $\left(\mathrm{aP}^{+} \mathrm{CD} 68^{-}\right.$ cells) (Table 2). In obese women, this proportion was significantly reduced to $\sim 17 \%$. There was no difference in the percentage of preadipocytes between UBO and LBO women or between depots in any of the groups.

\section{Macrophages}

The fraction of stromovascular cells that were macrophages $\left(\mathrm{aP} 2^{-} \mathrm{CD} 68^{+}\right.$plus $\mathrm{aP}^{+} \mathrm{CD} 68^{+}$cells) was significantly greater in obese than in lean women by ANOVA followed by Tukey testing. When ANOVA with age as a covariate was performed the differences between groups were no

Table 2 Adipose cell characteristics

\begin{tabular}{|c|c|c|c|}
\hline \multirow[t]{2}{*}{ Variable } & \multirow{2}{*}{$\begin{array}{l}\text { Lean } \\
(n=17)\end{array}$} & \multicolumn{2}{|l|}{ Obese } \\
\hline & & $\begin{array}{l}\text { Upper body } \\
(n=16)\end{array}$ & $\begin{array}{l}\text { Lower body } \\
(n=13)\end{array}$ \\
\hline \multicolumn{4}{|c|}{ Fat cell number per gram of tissue $\left(\times 10^{6}\right)$} \\
\hline Abdominal & $1.62 \pm 0.08^{\mathrm{a}, \mathrm{x}}$ & $1.00 \pm 0.08^{\mathrm{b}}$ & $1.03 \pm 0.08^{\mathrm{b}}$ \\
\hline Femoral & $1.08 \pm 0.08^{\mathrm{y}}$ & $0.97 \pm 0.08$ & $0.96 \pm 0.08$ \\
\hline \multicolumn{4}{|c|}{ Fat cell size ( $\mu \mathrm{g}$ lipid per cell) } \\
\hline Abdominal & $0.48 \pm 0.04^{\mathrm{a}, \mathrm{x}}$ & $0.75 \pm 0.05^{\mathrm{b}}$ & $0.76 \pm 0.05^{\mathrm{b}}$ \\
\hline Femoral & $0.67 \pm 0.04^{\mathrm{a}, \mathrm{y}}$ & $0.77 \pm 0.05^{\mathrm{b}}$ & $0.78 \pm 0.05^{\mathrm{b}}$ \\
\hline \multicolumn{4}{|c|}{ Preadipocytes $^{\mathrm{d}}(\%$ of stromovascular cells) } \\
\hline Abdomen & $30.6 \pm 2.8^{\mathrm{a}}$ & $17.0 \pm 3.0^{\mathrm{b}}$ & $17.3 \pm 3.1^{\mathrm{b}}$ \\
\hline Thigh & $30.5 \pm 2.8^{\mathrm{a}}$ & $17.4 \pm 3.0^{\mathrm{b}}$ & $17.2 \pm 3.1^{\mathrm{b}}$ \\
\hline \multicolumn{4}{|c|}{ Macrophages $^{\mathrm{d}}(\%$ of stromovascular cells) } \\
\hline Abdomen & $1.4 \pm 1.1$ & $5.4 \pm 1.2$ & $2.4 \pm 1.3$ \\
\hline Thigh & $1.6 \pm 1.1$ & $3.2 \pm 1.2$ & $3.6 \pm 1.2$ \\
\hline
\end{tabular}

Values are least squares means \pm SEM.

${ }^{a-c}, x, y$ Different superscripts within a row or within a column indicate significant difference $(p<0.05)$ among the groups or between the depots, respectively.

${ }^{\mathrm{d}}$ Preadipocytes are $\mathrm{aP} 2^{+} \mathrm{CD} 68^{-}$cells, macrophages are $\mathrm{aP}^{+} \mathrm{CD} 68^{+}$ and $\mathrm{aP} 2^{-} \mathrm{CD} 68^{+}$cells. longer statistically significant. In all groups, macrophages represented a small proportion of the stromovascular cells ( $\sim 1.5$ and $\sim 3.6 \%$ in lean and obese women respectively).

\section{Preadipocyte kinetics}

Experiments were performed in subsets of the UBO, LBO and lean groups to gain preliminary data regarding the proliferation, differentiation and apoptosis of subcutaneous preadipocytes. We found that preadipocytes of UBO women exhibited reduced differentiation and were more susceptible to apoptotic stimuli than preadipocytes isolated from adipose tissue of LBO and lean women (Table 3). Preadipocytes from lean and LBO women showed similar characteristics, whereas those from UBO women were different from lean and LBO preadipocytes. Because of the small numbers of samples studied, statistical analysis of this data was not considered to be helpful.

\section{Discussion}

This study was designed to test the hypothesis that body fat distribution phenotype is associated with differences in preadipocyte availability. To this end we recruited groups of UBO, LBO and lean women to assess adiposity, body fat distribution, adipocyte size, and the proportion of committed preadipocytes in the adipose stromovascular fraction from abdominal and femoral subcutaneous depots. We report for the first time that committed preadipocytes represent a considerable proportion $(30 \%)$ of the stromovascular cells of fresh subcutaneous adipose tissue in lean women. Moderate obesity is associated with a reduction in the percentage of preadipocytes in both femoral and abdominal depots irrespective of body fat distribution.

Table 3 Preadipocyte kinetics

\begin{tabular}{|c|c|c|c|}
\hline \multirow[t]{2}{*}{ Variable } & \multirow{2}{*}{$\begin{array}{l}\text { Lean } \\
(n=5)\end{array}$} & \multicolumn{2}{|l|}{ Obese } \\
\hline & & $\begin{array}{l}\text { Upper body } \\
(n=3)\end{array}$ & $\begin{array}{l}\text { Lower body } \\
(n=3)\end{array}$ \\
\hline \multicolumn{4}{|c|}{ Proliferation $\left(\% \mathrm{BrdU}^{+}\right.$cells $)$} \\
\hline Abdominal & $40.2 \pm 3.2$ & $51.3 \pm 6.0$ & $40.3 \pm 2.6$ \\
\hline Femoral & $45.8 \pm 3.9$ & $58.8 \pm 6.5$ & $48.8 \pm 3.1$ \\
\hline \multicolumn{4}{|c|}{ Differentiation $\left(\%\right.$ Oil Red $\mathrm{O}^{+}$cells $)$} \\
\hline Abdominal & $27.2 \pm 6.1$ & $10.3 \pm 1.9$ & $25.2 \pm 3.0$ \\
\hline Femoral & $16.0 \pm 7.8$ & $8.9 \pm 1.3$ & $34.2 \pm 6.1$ \\
\hline \multicolumn{4}{|c|}{ Apoptosis (\% apoptotic nuclei) } \\
\hline Abdomen & $47.2 \pm 3.4$ & $78.6 \pm 3.9$ & $55.2 \pm 5.4$ \\
\hline Thigh & $64.6 \pm 6.2$ & $85.5 \pm 4.1$ & $53.0 \pm 6.1$ \\
\hline
\end{tabular}

Data (means \pm SEM) are from cellular kinetics studies of preadipocytes from subcutaneous adipose tissue from three to five individuals per group. 
The anthropometric and metabolic parameters showed the characteristics expected of the two levels of adiposity and the two patterns of fat distribution in obesity, which were similar to previous descriptions of these obesity phenotypes. In this regard, considering previous reports it was somewhat surprising that the abdominal subcutaneous fat cell size was not larger in the UBO group than in the LBO group $[10,11]$. We suspect that this was because the previous studies included obese women with greater differences in WHR and lower average BMI. We speculate that the abdominal adipocytes in our obese women may almost have reached the maximum size, eliminating potential differences between the two obesity phenotypes that might be present at lower BMIs [12, 13]. The observation that obese women had a lower fat cell number per gram of tissue and larger fat cell size in the abdominal fat region compared with lean women suggests that hypertrophy of existing adipocytes contributes significantly to the expansion of this fat depot in obesity.

One of the early proteins that are expressed as multipotent stem cells commit to the adipocyte lineage is aP2 This attribute permits identification of the proportion of adipose stromovascular cells that are committed preadipocytes by simultaneous staining of subcutaneous adipose stromovascular cells for the markers aP2 (preadipocytes and aP2-expressing macrophages) and CD68 (macrophages). This permitted us to estimate the proportion of committed $\mathrm{aP}^{+} \mathrm{CD} 68^{-}$preadipocytes as well as the proportion of $\mathrm{aP} 2^{+} \mathrm{CD} 68^{+}$plus $\mathrm{aP} 2^{-} \mathrm{CD} 68^{+}$macrophages. We observed that subcutaneous preadipocytes represented a greater fraction of stromovascular cells in lean $(30 \%)$ than in moderately obese $(17 \%)$ women. In a previous study in severely obese women, we found that subcutaneous abdominal preadipocytes represented only $10 \%$ of the adipose stromovascular cells [2], suggesting that committed preadipocyte availability as a fraction of adipose stromovascular cells decreases as adiposity increases.

An important question is how the differences we observed between obese and non-obese women in the proportion of preadipocytes in subcutaneous adipose stromovascular cells translate into differences in the absolute number of preadipocytes. To answer this, we would need to know whether the number of stromovascular cells per gram of adipose tissue is different between lean and obese women. Data from our [2] and other laboratories $[14,15]$ collectively indicate that the number of stromovascular cells per gram of adipose tissue decreases moderately as BMI increases. This suggests that the lower percentage of preadipocytes (by $\sim 40 \%$ ) we observed in the obese groups should reflect an even greater decrease in the absolute number of committed subcutaneous preadipocytes.

The decrease in the fraction of committed preadipocytes as fat mass increases could be due to a number of factors. It is possible that preadipocytes have a limited ability to proliferate and thus as fat mass expands the total preadipocyte pool is distributed in a larger volume of tissue. Alternatively, there may be an almost unlimited number of preadipocytes, but in the obese state there is accelerated recruitment through the committed preadipocyte stage to mature fat cells. Another possibility is greater preadipocyte susceptibility to apoptosis. To investigate which of these dynamic processes might contribute to the smaller fraction of committed preadipocytes in different obesity phenotypes, we studied preadipocyte proliferation, differentiation and susceptibility to apoptosis in stromovascular cultures from a small subset of lean, UBO and LBO women. We found that preadipocyte dynamics were similar in lean and LBO women, whereas preadipocytes from UBO women differentiated less readily and were more susceptible to apoptosis. Consistent with our findings, Permana et al. [16] showed that subcutaneous abdominal preadipocyte differentiation correlated inversely with central obesity. If our preliminary data can be confirmed, this suggests that the reduced fraction of committed preadipocytes we see in UBO and LBO women may be due to different mechanisms, i.e. it may occur via the process of differentiation into newly formed fat cells in LBO women vs apoptosis in UBO women. The preserved potential for differentiation in LBO women may suggest competence of the subcutaneous adipose tissue to expand with weight gain. Our preliminary data suggest that, in UBO, the subcutaneous adipose tissue may be less able to expand because of inhibited differentiation. Such an interpretation is in harmony with the hypothesis that the inability of subcutaneous adipose tissue to expand in the face of excess fat storage drives the accumulation of fat in the visceral depots or in ectopic sites [17].

We observed that macrophages constituted $\sim 1.5 \%$ of the cells in the abdominal stromovascular fraction in lean women and $\sim 4 \%$ of the cells in the moderately obese women. In women with severe obesity $\left(n=6\right.$, BMI $\left.>40 \mathrm{~kg} / \mathrm{m}^{2}\right)$, the proportion of macrophages was considerably greater, at $\sim 14 \%$ [2]. These data support previous reports on macrophage infiltration with increasing BMI [18], particularly when BMI exceeds $35 \mathrm{~kg} / \mathrm{m}^{2}$.

In summary, obesity in women is associated with a reduction in the percentage of preadipocytes in both the femoral and the abdominal depots, irrespective of body fat distribution. However, a preliminary study of preadipocyte proliferation, differentiation and apoptosis suggests that the cellular kinetics of preadipocytes may be linked to fat distribution more closely than the proportion of preadipocytes. We hope that these data will enhance our understanding of the roles of preadipocytes and adipogenesis in determining body fat distribution. 
Acknowledgements This work was supported by grants DK45343, DK50456 and RR00585 from the US Public Health Service and by the Mayo Foundation. The authors thank C. Morris, J. Eastman and C. Siverling of the Mayo Clinic for technical assistance and X. Fang of Pennington Biomedical Research Center for help with the statistical analysis.

Duality of Interest None of the authors have a duality of interest with regards to this work.

\section{References}

1. Arner P (1997) Regional adiposity in man. J Endocrinol 155:191192

2. Tchoukalova YD, Sarr MG, Jensen MD (2004) Measuring committed preadipocytes in human adipose tissue from severely obese patients by using adipocyte fatty acid binding protein. Am J Physiol Regul Integr Comp Physiol 287:R1132R1140

3. Jensen MD, Haymond MW, Rizza RA et al (1989) Influence of body fat distribution on free fatty acid metabolism in obesity. J Clin Invest 83:1168-1173

4. Shadid S, Jensen MD (2003) Effects of pioglitazone vs diet and exercise on metabolic health and fat distribution in upper body obesity. Diabetes Care 26:3148 - 3152

5. Folch J, Lees M, Sloane Stanley GH (1957) A simple method for the isolation and purification of total lipids from animal tissues. J Biol Chem 226:497-509

6. Tchoukalova YD, Harteneck DA, Karwoski RA et al (2003) A quick, reliable, and automated method for fat cell sizing. J Lipid Res 44:1795-1801

7. Tchkonia T, Tchoukalova Y, Giorgadze N et al (2005) Abundance of two human preadipocyte subtypes with distinct capacities for replication, adipogenesis, and apoptosis varies among fat depots. Am J Physiol Endocrinol Metab 288:E267E277

8. Hausman GJ (1981) Techniques for studying adipocytes. Stain Technol 56:149-154

9. Fischer-Posovszky P, Tornqvist $\mathrm{H}$ et al (2004) Inhibition of deathreceptor mediated apoptosis in human adipocytes by the insulinlike growth factor I (IGF-I)/IGF-I receptor autocrine circuit. Endocrinology 145:1849-1859

10. Garaulet M, Perex-Llamas F, Fuente T et al (2000) Anthropometric, computed tomography and fat cell data in an obese population: relationship with insulin, leptin, tumor necrosis factor-alpha, sex hormone-binding globulin and sex hormones. Eur J Endocrinol 143:657-666

11. Kissebah AH, Vydelingum N, Murray R et al (1982) Relation of body fat distribution to metabolic complications of obesity. J Clin Endocrinol Metab 54:254-260

12. Gurr MI, Jung RT, Robinson MP et al (1982) Adipose tissue cellularity in man: the relationship between fat cell size and number, the mass and distribution of body fat and the history of weight gain and loss. Int J Obes 6:419-436

13. Krotkiewski M, Bjorntorp P, Sjostrom L et al (1983) Impact of obesity on metabolism in men and women: importance of regional adipose tissue distribution. J Clin Invest 72:1150-1162

14. O'Brien SN, Mantzke KA, Kilgore MW et al (1996) Relationship between adipose stromal-vascular cells and adipocytes in human adipose tissue. Anal Quant Cytol Histol 18:137-143

15. Van Harmelen V, Skurk T, Rohrig K et al (2003) Effect of BMI and age on adipose tissue cellularity and differentiation capacity in women. Int J Obes Rel Metab Disord 27:889-895

16. Permana PA, Nair S, Lee YH et al (2004) Subcutaneous abdominal preadipocyte differentiation in vitro inversely correlates with central obesity. Am J Physiol Endocrinol Metab 286: E958-E962

17. Danforth E Jr (2000) Failure of adipocyte differentiation causes type II diabetes mellitus? Nat Genet 26:13

18. Weisberg SP, McCann D, Desai M et al (2003) Obesity is associated with macrophage accumulation in adipose tissue. J Clin Invest 112:1796-1808 